\title{
Helicobacter Pylori and Gastric Cancer
}

\author{
Snežana V. Živković-Perišić \\ Institute of Public Health of Serbia „dr Milan Jovanović Batut”, Belgrade, Serbia
}

\section{SUMMARY}

Introduction: According to GLOBOCAN estimates for 2018, gastric cancer was the fifth most common cancer and the third most common cause of death from malignant diseases in the world. Although the etiology of this cancer is multiple, Helicobacter pylori infection is strongly associated with the development of gastric cancer.

Methodology: A review of professional international journals and public health publications related to the association of Helicobacter pylori infection and gastric cancer

Topic: As early as 1994, the International Agency for Research on Cancer and the World Health Organization identified Helicobacter pylori as a type I carcinogen in humans, although the exact mechanism of carcinogenesis has not yet been clearly established. Carcinogenesis is also influenced by environmental factors, as well as genetic diversity, which can lead to different inflammatory responses and thus affect the clinical outcome of the disease. Chronic gastritis caused by Helicobacter pylori infection is the strongest known risk factor for the development of adenocarcinoma of the distal part of the stomach. The effect of eradicating Helicobacter pylori infection is seen in the reduced risk of gastric cancer, but several therapeutic attempts to prevent the development of gastric tumors by eradicating Helicobacter pylori infection have yielded minimal results. In an attempt to elucidate this problem in high-risk populations, researchers began conducting prospective randomized, double-blind population studies. The results of previous studies have highlighted the importance of long-term and careful monitoring of patients after eradication therapy, but there are still multiple deviations („enigmas”) that call into question the cause-effect relationship between $H$. pylori and gastric cancer.

Conclusions: It has been established that the eradication of Helicobacter pylori, in order to prevent gastric cancer, is effective only when it is carried out before the development of premalignant changes: atrophy, metaplasia, and dysplasia of the gastric mucosa. In addition, the significant treatment efficacy observed in younger patients suggests the need to eradicate Helicobacter pylori infection as early as possible.

Keywords: Helicobacter Pylori Infection, Carcinogenesis, Gastric Carcinoma

\section{INTRODUCTION}

Despite a significant global reduction in gastric cancer incidence rate, it remains an important public health problem $[1,2,3]$. Gastric cancer ranks fifth in incidence among all malignancies and is the cause of about 800,000 cancer deaths worldwide annually $[1,2,3]$. High mortality of patients is caused by late clinical manifestations of the disease, i.e. diagnosing an already advanced disease, as well as still modest therapeutic options [4,5,6,7]. A small number of countries in the world, such as Japan, have a successful strategy for recognizing early gastric cancer in a significant number of individuals. People with early gastric cancer

Corresponding author:

Snežana V. Živković-Perišić, MD, MS

Specialist in Epidemiology

Institute of Public Health of Serbia „dr Milan Jovanović Batut”, dr Subotića 5, Belgrade, Serbia

E-mail: perisici4@gmail.com 
are a group of patients with a high potential for treatment and cure either by surgery (standard gastrectomy and non-standard gastrectomy) or by endoscopic resection (endoscopic mucosal resection (EMR) or endoscopic submucosal dissection (ESD)) [8].

Helicobacter pylori was categorized as a class I (definite) carcinogen and the carcinogenic potential of infection with this bacterium is based on epidemiological data, in vitro and in vivo experimental models, as well as on the results of clinical observations and therapeutic studies. The results of the study showed that there are multiple deviations („enigmas”) that call into question the cause-and-effect relationship between $H$. pylori infection and gastric cancer. Thus, the incidence of gastric cancer in men is higher (2-3 times higher) with almost equal seroprevalence of infection between the sexes („sexual enigma”). Further, the high prevalence of $H$. pylori infectionin some areas with a low risk of gastric cancer („Mediterranean enigma” or „African enigma”). Patients with duodenal ulcers rarely develop cancer, although they are usually all infected („peptic ulcer enigma”). Also, differences in the prevalence of infection at a younger age do not correlate with gastric cancer mortality („younger enigma”). Finally, the difference between the total number of infected and those who develop gastric cancer (1-3\% of infected) is the least clear. Gastric carcinogenesis is a very complex process, and $H$. pylori infection is one of the risk factors. $H$. pylori infection is the main cause of chronic gastritis, a condition that is a recognized trigger of pathological changes in the gastric mucosa, leading to atrophic gastritis, meta- plasia, dysplasia, and cancer [9]. Analyzes of prospective seroepidemiological studies have shown that $H$. pylori-positive individuals carry a statistically significantly higher risk of developing noncardiac gastric cancer. Although $H$. pylori infection has been unequivocally proven to be the most common risk factor in the development of gastric cancer, the influence of cofactors such as bacterial virulence factor and proinflammatory host and environmental factors should not be overlooked. The process of carcinogenesis is the result of their complex interaction $[9,10]$.

\section{METHODOLOGY}

A review of professional international journals and public health publications related to the association of Helicobacter pylori infection and gastric cancer.

\section{TOPIC}

\section{Epidemiological data}

The prevalence of a disease, condition, or infection represents a balance between the frequency and duration of the disease/condition/ infection in the community. In the case of $\mathrm{He}$ licobacter pylori infection, once introduced the infection lasts for years (decades), and spontaneous eradication is extremely rare [11]. Infection is present in all parts of the world. But there are large differences in the prevalence of infection between countries as well as between different ethnic groups, different age groups, and their socioeconomic status. More than $50 \%$ of the world's population is infected

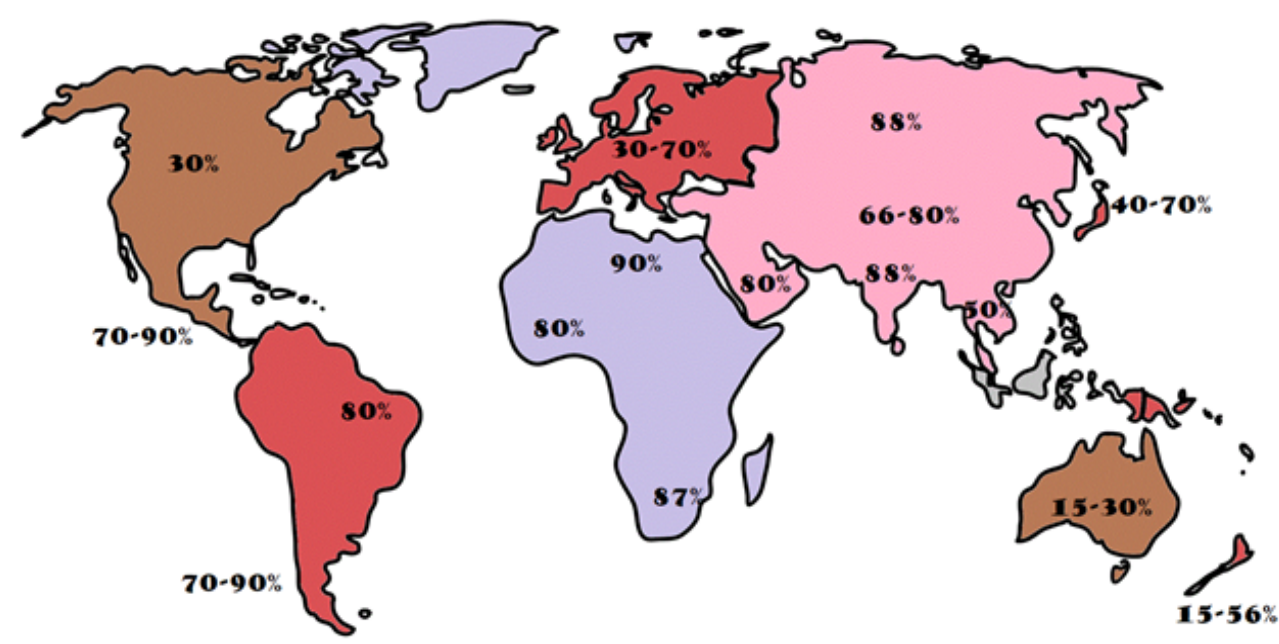

Figure 1. Global Prevalence of Helicobacter pylori Infection: Systematic Review and MetaAnalysis [12] 
with $H$. pylori, and the prevalence of infection in developing countries is higher than $80 \%$ in adults over 50 years of age. Infected people usually become infected before the age of 10 and grow up with the infection present [11].

Epidemiological data show that the overall prevalence of $H$. pylori infection in the world ranges between 7 and $87 \%$. The highest prevalence was recorded in Asia, while the average prevalence in European countries was about $30 \%$ and was lower in the north compared to the southern and central-eastern countries of Europe [11].

Epidemiological studies have shown that prevalence is closely related to socioeconomic factors such as overcrowding and poor sanitation. Accordingly, by improving hygienic and living conditions in general, the prevalence of infection can be reduced. Prevalence of $H$. pylori infection correlates best with socioeconomic status rather than race. In the United States, probability of being infected is greater for older persons $(>50$ years $=>50 \%)$, minorities (African Americans 40-50\%) and immigrants from developing countries (Latino $>60 \%$, Eastern Europeans $>50 \%$ ). The infection is less common in more affluent Caucasians $(<40$ years $=20 \%)$ (Figure 1.).

H. pylori infection continues to be a major public health issue. The global comprehensive and up-to-date systematic review of the worldwide prevalence of $H$. pylori shows that in 2015 , approximately 4.4 billion individuals worldwide were estimated to be positive for $H$. pylori. It was confirmed a wide variation in the prevalence of $H$. pylori between regions and countries. Prevalence is highest in Africa
(79.1\%), Latin America and the Caribbean (63.4\%), and Asia (54.7\%). In contrast, H. pylori prevalence is lowest in Northern America (37.1\%) and Oceania (24.4\%) (Figure 2.).

At the turn of the $21^{\text {st }}$ century, the prevalence of $H$. pylori has been declining in highly industrialized countries ofthe Western world, whereas prevalence has plateaued at a high level in developing and newly industrialized countries. The widening differential gap in prevalence has important implications on the future worldwide prevalence of sequelae associated with $H$. pylori, including peptic ulcer disease and gastric cancer. These differences in H. pylori prevalence likely reflect the level of urbanization, sanitation, access to clean water, and varied socioeconomic status [12].

Prevalence studies have shown that over $90 \%$ of gastric cancers are associated with $H$. pylori infection $H$. pylori also causes active chronic gastritis in all infected patients and clinical ulcers of the stomach and duodenum. MALT lymphomas and gastric cancer are the result of an infection in 20\% of those who are infected. Countries with a high incidence rate of gastric cancer usually have a high prevalence of $H$. pylori infection, and a decrease in the prevalence of $H$. pylori in developed countries is accompanied by a decrease in the incidence of gastric cancer. The exception is Africa, where $H$. pylori infection is common, while gastric cancer is still rare $[13,14]$.

International Agency for Research on Cancer (IARC) estimates that about 36\% of gastric cancers in developed countries and $47 \%$ of cases in developing countries are associated with $H$. pylori infection. It is also
Figure 2. Global Prevalence of Helicobacter pylori Infection: Systematic Review and MetaAnalysis [12]

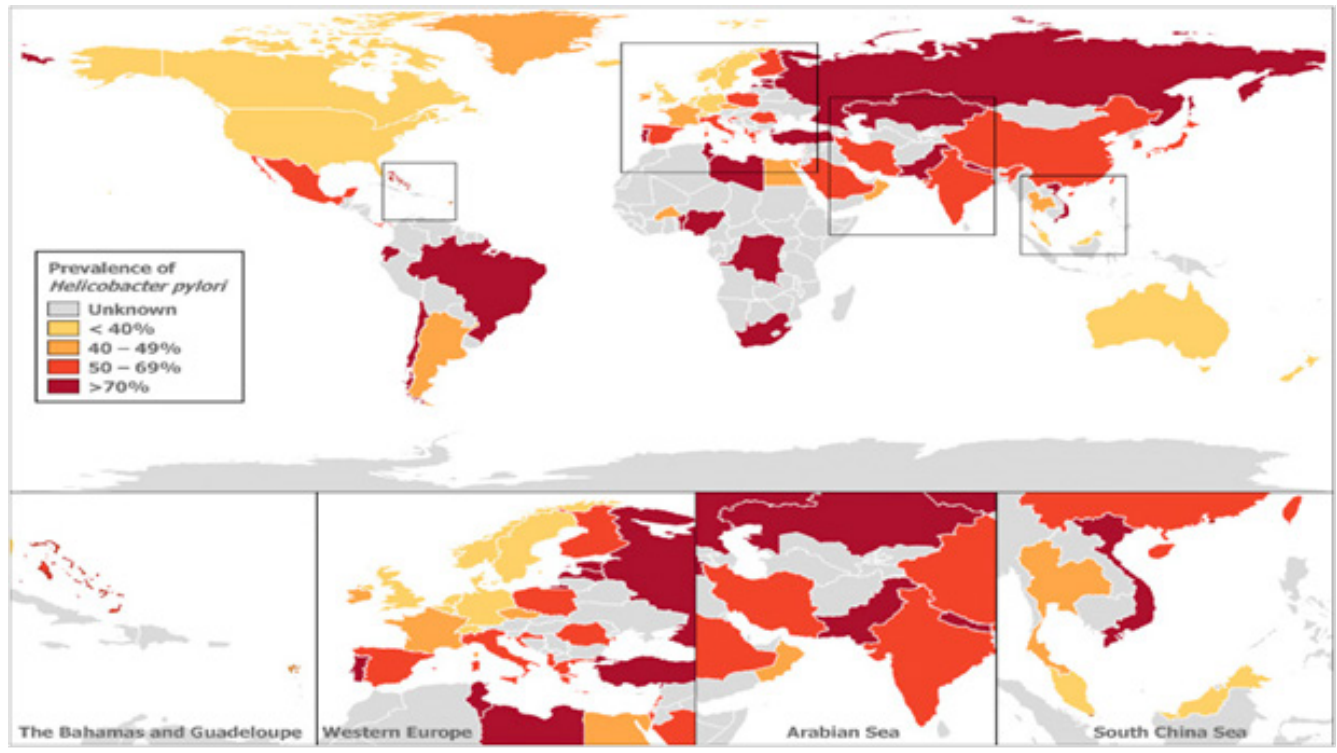


estimated that about 65 to $80 \%$ of all gastric cancers, except cardiac, are caused by H. pylori infection. However, it is known that only $1 \%$ of those infected develop stomach cancer. Numerous clinical studies have followed an association between $H$. pylori infection and gastric cancer [13]. The results of various studies on the reversibility of atrophy and/or intestinal metaplasia after eradication of this infection are inconsistent. Most of the results of these studies show reversibility of atrophy, but not intestinal metaplasia. One of the more significant is that in which Fukase et al. in a prospective, randomized, placebo-controlled study of 272 patients in each group showed a significant reduction in the risk of developing metachronous gastric cancer after $H$. pylori eradication. The study was discontinued for ethical reasons, and based on the results obtained, the Japanese Society for the Study of $H$. pylori infection changed the recommendations for the treatment of this infection and now the eradication of the infection is recommended for all infected patients. Probably the strongest evidence for this association comes from a prospective study that included 1,526 Japanese patients who developed stomach cancer. Cancer was registered in $2.9 \%$ of infected subjects, but none of the uninfected subjects 26 developed gastric cancer [14].

Several studies have shown that $H$. pylori infection is equally associated with both intestinal and diffuse gastric cancers, and epidemiological studies show that $H$. pylori infection is more associated with distal and less with proximal gastric cancer $[15,16,17]$. In developed countries, the declining incidence of $H$. pylori infection and the incidence of noncardiac cancer are opposed to the rapid increase in the incidence of cardiac cancer. Other studies have shown a significant inverse relationship between infection, especially CagA + strains, and the development of gastric cardia and esophageal cancer. In western countries where the prevalence of $H$. pylori is declining, the incidence of GERD (gastroesophageal reflux disease) and its sequelae is increasing $[15,16,17]$. Studies have shown that severe atrophic gastritis and hypochlorhydria (decreased production of stomach acid) associated with $H$. pylori infection significantly reduce the risk of developing GERD. However, recent studies have not shown with certainty that eradication of $H$. pylori infection increases the risk of esophagitis and gastric cardiac can- cer. Therefore, the protective effect of $H$. pylori infection in the development of gastric cardiac cancer remains a matter of discussion $[17,18]$.

H. pylori infection is associated with different clinical entities and always causes inflammatory changes in the gastric mucosa or gastritis. The type and intensity of gastritis determine the clinical manifestation of the disease. The overall prevalence of $H$. pylori infection is $28.7 \%$ in superficial gastritis, $57.7 \%$ in erosive gastritis, $80.8 \%$ in gastric and duodenal ulcers, and $52.4 \%$ in early gastric cancer [19]. A meta-analysis of 12 epidemiological studies from 2000 showed that $H$. pylori infection increases the risk of developing gastric cancer by up to three times more than in the uninfected population. Patients with positive serological findings for $H$. pylori infection ten or more years before the onset of cancer were six times more likely to develop gastric cancer than those with negative serological tests. A meta-analysis of six other studies involving about 7,000 patients (most of whom were of Asian descent), followed for 4 to 10 years, showed that the relative risk (RR) of gastric cancer after $H$. pylori eradication was 0.65 (95\% CI 0.43 - 0.98). The same studies showed a significant reduction in the incidence of gastric cancer, using eradication therapy, only in patients with normal pepsinogen levels. This fact suggests that the development of gastric cancer after eradication of $H$. pylori depends on the degree of gastric atrophy before starting therapy.

The main reservoir of $H$. pylori is human, and the routes of transmission are: direct contact from person to person through the fecal route, oral-oral or gastrooral route, but consumption of contaminated water and food increases the risk of $H$. pylori infection. H. $p y$ lori infection occurs in childhood, and infection usually occurs before the age of ten. Most people infected with $H$. pylori do not develop significant clinical complications, but endoscopy reveals signs of asymptomatic chronic gastritis.

\section{Pathogenesis of H. Pylori ingastric carcinogenesis}

The course of $H$. pylori infection depends on 3 groups of factors:

a) Virulence and pathogenicity of bacteria

b) Environmental factors

c) Host factors. 
Virulence and pathogenicity factors of Helicobacter pylori

H. pylori is characterized by high gene variability, so that the occurrence of different isolates in the same individual over time is possible due to changes in DNA structure, recombinant events, and endogenous mutations. The described potentials enable the bacteria to more easily adapt to the defense of the individual mucosa, but they also make it difficult to precisely define the true role of virulence in the pathogenesis of gastric cancer. The direct mutagenic effect of $H$. pylori has been shown in animal models associated with the duration of infection. Nuclear and mitochondrial DNA instability associated with $H$. pylori infection has been reported in gastric cell culture studies. Factors identified so far that certainly affect H. pylori virulence are CagA protein (from the cytotoxin-associated gene A), followed by the vacuolar cytotoxin VacA (Vacuolating cytotoxin A), and outer membrane protein BabA, which is today attributed to a particularly important role in gastric carcinogenesis [20].

\section{The role of CagA pathogenic bacteria in gastric carcinogenesis}

CagA-positive strains of $H$. pylori are associated with stronger inflammation of the gastric mucosa and a significantly higher risk of gastric cancer. These strains of $H$. pylori contain a genomic region known as Cag-PAI responsible for the so-called type IV secretion that releases CagA directly into gastric epithelial cells. An important role in this process is played by the CagL protein primarily on target gastric epithelial cells. After translocation into host cells, CagA is phosphorylated and activated by mitogen-activated protein kinases, which dephosphorylate host defense cells and make morphological changes in the epithelium via tyrosine phosphatase. CagA can also lead to the activation of the so-called, Ras-Erk pathway that raises the level of IL-8 and NFB. Activation of these pathways can lead to various pathological host responses such as disruption of apical epithelial cell junctions, loss of cell polarity with enhanced inflammatory and mitogenic activity. Studies indicate a significant difference between the so-called eastern and western subtypes of CagA-positive strains of $H$. pylori and emphasize significantly higher virulence of so-called eastern strains.
Geographical differences in Helicobacter pylori oncogenic potentials are reflected in significantly different incidences of gastric cancer in different parts of the world $[20,21,22,23]$.

2. The role of cytotoxin VacA and membrane protein BabA in gastric carcinogenesis

VacA toxin is an important virulence factor of H. pylori. The toxin causes numerous cellular activities, such as vacuolation, changes in the structure of membrane channels, apoptotic events, and immunomodulation. For example, VacA stops T-lymphocyte proliferation by stopping the G1 phase of the cell cycle. The toxin is present in all $\mathrm{H}$. pylori strains, however, certain alleles $(\mathrm{s} 1, \mathrm{~m} 1)$ are more strongly correlated with CagA expression, which in combination leads to increased cell damage. Depending on the geographical location, $40-95 \%$ of $H$. pylori strains have a pronounced expression of BabA outer membrane protein. The significance of this protein is in increasing the adhesive capacity of the bacterium on the gastric epithelium. Patients infected with BabA strains show denser bacterial colonization and stronger inflammatory activity due to increased levels of IL-8.47. The presence of BabA, s1-alleles VacA and CagA in the bacterium carries the highest risk of carcinogenesis [24].

\section{Host factor}

Host factors associated with an increased risk of developing gastric cancer include gene polymorphism leading to high expression of the proinflammatory cytokine interleukin- $1 \beta$. This increases the risk of developing gastric cancer and its precursor lesions in the presence of $H$. pylori infection within which its level increases. Genetic factors that affect IL-1 expression may determine why some people infected with $H$. pylori develop stomach cancer, unlike others. H. pylori significantly reduces the bioavailability of vitamin $\mathrm{C}$, which leads to damage to the antioxidant capacity of the mucosa. Also, after $H$. pylori infection, there is a strong activation and accumulation of neutrophils in the gastric mucosa that produce inducible nitric oxide synthase (iNOS) and release nitric oxide and reactive oxygen metabolites such as superoxide and hydroxyl ions that damage DNA accompanied by gene mutation and consequent malignancy. Another host factor 
that appears to influence the development of gastric cancer in chronic $H$. pylori infection is gastrin, which is known to stimulate the proliferation of gastric epithelial cells and cancer cells. Hypergastrinemia after the development of gastric cancer in experimental animals is associated with strong expression of certain growth factors, COX-2-prostaglandin system, and antiapoptotic proteins such as Survivin and $\mathrm{Bcl} 2$, which leads to mutation of mutated atrophic cells, strong angiogenesis, and gastric cancer. In addition to gastrin, there are several other growth factors expressed in carcinogenesis caused by $H$. pylori infection. Increased mucosal gene expression and release of epidermal growth factor (EGF) and TGF- $\alpha$ (transforming growth factor-alpha) into the gastric lumen, as well as other growth factors in patients with gastric cancer due to infection, are normalized after eradication of $H$. pylori [25].

\section{The role of patients' genetic predisposition in carcinogenesis}

Recent studies have paid increasing attention to genetic factors of the host that are important in the outcome of $H$. pylori infection as well as in the anatomical distribution of the infection. Polymorphism of several host genes is associated with an increased risk of gastric cancer. Patients with IL- $1 \beta$ and IL- 1 receptor gene polymorphisms show a twofold to threefold increased risk of developing gastric cancer. IL$1 \beta$ is a potent proinflammatory cytokine that is released in patients infected with $H$. pylori and is also a potent inhibitor of gastric secretion. Polymorphism of this gene contributes to an increased risk of developing distal gastric cancer. Another pro-inflammatory cytokine is TNF- $\beta$, which is also produced in the gastric mucosa of $H$. pylori. The polymorphism of this gene, as well as the IL-16 gene, predisposes the host infected with $\mathrm{H}$. pylori to develop gastric cancer. Interferon $\beta$, which produces Th1 cytokines that support gastritis, is also considered very important. Immunoregulatory gene polymorphisms are also important, including functional polymorphisms of innate immune response receptors such as toll-like receptors, which also increase the risk of carcinogenesis by up to ten-fold. In addition, a wide range of other genetic and epigenetic abnormalities have been described, such as point mutations in DNA that disrupt the expression and function of cell growth inhibitor genes, loss of het- erozygosity, microsatellite instability, and hypermethylation. In clinical practice, however, there are currently no specific markers that could be recommended for gene testing [25].

\section{The role of environmental factors in carcinogenesis}

In the development of gastric cancer, great importance has long been attached to the influence of environmental factors, especially diet. High salt intake, traditionally salted meat preparations, fish, vegetables, fried foods, and alcohol are accompanied by an increase in morbidity by the mechanism of increased production of nitroso compounds and reactive oxygen radicals, ie acetaldehyde introduced by alcoholic beverages, but also an endogenous form of them. The risk of malignant changes increases due to damage to DNA levels.14 Acetaldehyde is also a relevant carcinogen in connection with $H$. pylori infection, especially in patients with atrophic gastritis. In addition to salt-saturated foods, foods rich in nitrogen compounds and alcohol consumption and smoking are important predisposing factors for gastric carcinogenesis, especially in light of the findings that the onset of smoking is usually associated with adolescence and $H$. pylori infection in early childhood. As is well known, the onset of exposure to carcinogens in adolescence and childhood contributes in many ways to the development of cancer. There is a strong association of smoking with cardiac gastric adenocarcinoma, while an association with other localizations of gastric cancer and smoking has not been proven with certainty. Most studies analyzing the association of environmental and dietary factors with gastric cancer do not assess $H$. pylori status [26,27,28,29].

\section{Precancerous lesions}

The clinical significance of precancerous lesions was confirmed in a large Dutch study by Vries et al., which retrospectively assessed 92,250 patients from the National Registry between 1991 and 2005. Among these patients, 22,365 (24\%) patients were diagnosed with atrophic gastritis, 61,707 (67\%) patients with intestinal metaplasia, 7,616 (8\%) patients with mild or moderate dysplasia, and $562(6 \%)$ with severe gastric dysplasia. Gastric cancer has been reported in $0.1 \%$ of patients with atrophic gastritis, $0.25 \%$ of patients with intestinal 
metaplasia, $0.6 \%$ of patients with mild and moderate dysplasia, and as many as $6 \%$ of patients with severe dysplasia (HR 40,14, CI 32, 2 - 50.1). Separate risk factors were male gender and older age [30].

The risk of developing gastric cancer in patients with mild to moderate dysplasia is comparable to the risk of developing colorectal cancer after adenoma removal. However, for now, there are no clear recommendations on the intervals of endoscopic follow-up of these patients, which imposes the need for further prospective studies. For now, endoscopic monitoring of patients with moderate and severe gastric atrophy at check-up intervals of 2 to 3 years, and patients with dysplasia at intervals of 3 to 6 months is recommended $[30,31,32]$.

There are direct and indirect indications that atrophic corpus gastritis leads to hypochlorhydria, with consequent bacterial overgrowth of the gastric mucosa of these patients. Bacterial enzymes reduce nitrates to nitrites with consequent elevated intralum levels, and carcinogenic $\mathrm{N}$-nitrosamines. As already mentioned, ascorbic acid (vitamin C) is an antioxidant that reduces the concentration of N-nitrosamine, as well as reactive oxidants in the gastric mucosa and thus has a protective role in carcinogenesis. $H$. pylori infection lowers the concentration of ascorbic acid, and in the conditions of achlorhydria the concentration of ascorbic acid becomes almost immeasurable $[31,32]$.

Morphological changes of the gastric mucosa in $H$. pylori infection show that the development of gastric cancer is extremely rare in the absence of chronic active gastritis and that the degree and topographic extent of intestinal metaplasia and atrophy of the gastric mucosa are proportionally related to the incidence of gastric cancer [32].

\section{Prevention}

Today, the importance of eradicating $H$. pylori in young patients is emphasized. Population studies conducted in China to detect early gastric cancer in young people show that a quality endoscopic examination detects only one in four to six gastric cancers [33]. In the pharmacoeconomic sense, today's views give preference to eradication therapy of $H$. pylori infection in children and young people in connection with endoscopic screening methods in regions with a high incidence of this disease $[33,34,35,36]$. This topic is still debated, especially because of the risk of re-infection. The percentage of re-infection is low in developed countries, while in developing countries it is around $13 \%$. This information should be kept in mind when planning a prevention strategy and repeating eradication therapy $[33,34,35,36]$.

Eradication of $H$. pylori infection, in addition to the prevention of gastric cancer, brings additional clinical and pharmacoeconomic benefits. Eradication therapy has been shown to prevent the development of gastric or duodenal ulcers [37]. In addition, H. pyloriinfected patients on acetylsalicylic acid therapy have an increased risk of developing mucosal lesions. By eradicating $H$. pylori infection, we indirectly reduce the potential interaction between proton pump inhibitors and antiplatelet drugs in the future. $H$. pylori eradication therapy is also known to prevent the development of gastric MALT lymphoma, sideropenic anemia, idiopathic thrombocytopenic purpura, lymphocytic gastritis, and Menetrier's disease. Finally, eradication that helps heal gastritis leads to a reduction in mortality due to gastritis itself but also reduces future costs of treating complications and other diseases associated with $H$. pylori infection $[38,39]$.

All studies published so far confirm the positive effect of eradication in cancer prevention, with critical reviews in the necessary subsequent meta-analyses. Successful eradication in the absence of premalignant lesions will completely lead to the normalization of epithelial structures in the stomach. However, the limiting factor is the fact that once detected premalignant lesion (gastric atrophy, intestinal metaplasia, dysplasia) remains „stable" and eradication $H$. pylori infection, does not necessarily mean that further carcinogenesis can be stopped or completely prevented. The discussion of the most favorable time for eradication therapy continued in a Japanese study on 4,133 patients with peptic ulcer disease. In this five-year study, the incidence of gastric cancer was $1.24 \%$ in patients with $H$. pylori eradication and $2.56 \%$ in those without H. pylori. There appears to be a critical point at which eradication therapy of $H$. pylori infection does not play a further role in cancer prevention. The assumption that changes such as severe gastric atrophy and intestinal metaplasia have not been firmly established, since 
cancer is detected only in a certain number of these patients. Vatari et al investigated the effect of $H$. pylori eradication on the appearance of cells in already expressed intestinal metaplasia and proved that eradication can affect the phenotypic characteristics of metaplasia, however, regression of histological changes after eradication was not observed. It has been unequivocally proven that gastric atrophy can be reversible if it is present only in the gastric body, while intestinal metaplasia is mostly an irreversible change. The characteristics of different phenotypes of intestinal metaplasia are still being investigated, to identify a phenotype that shows a tendency for further histological progression to cancer $[39,40]$.

In regions with a low incidence of gastric cancer, it is necessary to identify patients at high risk of developing this disease. These are close relatives of patients with gastric cancer in whom the risk of developing cancer is two to three times higher than in the control population. If there are several patients with gastric cancer in the family, the risk of the disease increases tenfold. Patients with a mutation in the $\mathrm{CDH}-1$ gene require consultation with a geneticist and prophylactic gastrectomy. Risk groups with an absolute indication for eradication therapy include patients with previous gastric surgery, patients with history of gastric neoplasm (MALT lymphoma, adenocarcino$\mathrm{ma})$, patients with pangastritis, and patients with gastritis occurring in the gastric corpus. Patients who have taken proton pump inhibitors for more than 12 months and patients scheduled for long-term treatment with these drugs also have an increased risk of developing gastric cancer. Patients exposed to one or more risk factors for developing gastric cancer such as smoking, exposure to contaminants such as dust, cement, coal, flint, as well as patients living in regions with a high incidence of gastric cancer must be treated with $H$. pylori infection by applying eradication therapy [41].

\section{Future directions}

Prevention throughout behavioral management and $H$. pylori eradication may be an important to reduce the occurrence of gastric cancer.A unique contrivance on potential dietary or other chemopreventive agents and related well-designed studies are required. In addition, it is important to take into account whom to eradicate, when to eradicate, and what regimen to use to eradicate $H$. pylori in the general population [42]. In the future it is necessary to develop academic cooperation, by monitoring the trend in the incidence of both Helicobacter pylori infection and gastric cancer and set a strategy for the prevention and treatment of $H$. pylori infection through and within European and international networks [43]. In $\mathrm{H}$. pylori eradication strategy planning is also necessary to establish good response and strong study (population and/or patient based) and advanced statistical data processing on the other hand [44].

\section{CONCLUSION}

Helicobacter pylori infection is the most widespread infection globally and it infects half of the world's population. Most of those infected are asymptomatic. Over $95 \%$ of people with chronic gastritis also have $H$. pylori infection. The indisputable importance of infection is in the development of malignant gastric tumors. In the first study by Warren and Marshall, 1981, the hypothesis was confirmed but not accepted that the cause in $95 \%$ of duodenal ulcers and in $70 \%$ of gastric ulcers is $\mathrm{H}$. pylori infection. The study also established the basic guidelines in the treatment of Helicobacter pylori infection using the double-blind test method of antibacterial treatment of peptic ulcer. The result of the study is that after the eradication of the infection, there is much less recurrence of ulcers, and that the histological changes on the gastric mucosa are corrected and withdrawn. All subsequent studies have proven the benefit of eradication therapy of the infection by applying two drugs together, when the effect grows to $50 \%$, or by applying three or four drugs together, a success rate of eradication of $95-100 \%$ is achieved. H. pylori was categorized as a class I (definite) carcinogen and the carcinogenic potential of infection with this bacterium is based on epidemiological data, in vitro and in vivo experimental (animal) models, as well as on the results of clinical observations and therapeutic studies. The intestinal type of gastric cancer develops through 4 phases of pathohistological changes (inflammatory process - metaplasia - dysplasia - cancer). The basic finding that stratifies patients into two groups is the finding of epithelial dysplasia. Patients with atrophy and intestinal metaplasia without dysplasia are checked every 2-3 years, and patients with dysplasia much more often. In 
the case of low-grade dysplasia, an endoscopic examination should be repeated at intervals not longer than 12 months and always with a sufficient number of histological samples. By identifying and actively monitoring these patients, the early diagnosis of gastric cancer can be improved, at the stage when the disease is largely cured, with the recommendation that eradication therapy is performed in every patient with $H$. pylori infection. Standardization of procedures in terms of endoscopic procedures and the application of eradication therapy would bring great benefits to patients, and at the same time enable the redistribution of financial resources to patients at the greatest risk. These can be very important measures in reducing the incidence and mortality of gastric cancer in developing countries, but also in developed countries.

\section{REFERENCES}

1. Ferlay J, Ervik M, Lam F, Colombet M, Mery L, Piñeros M, Znaor A, Soerjomataram I, Bray F (2018). Global Cancer Observatory: Cancer Today. Lyon, France: International Agency for Research on Cancer. Available from: https://gco.iarc.fr/today/

2. Bray F, Ferlay J, Soerjomataram I, Siegel RL, Torre LA, Jemal A (2018). Global cancer statistics 2018: GLOBOCAN estimates of incidence and mortality worldwide for 36 cancers in 185 countries. CA Cancer J Clin. 68(6):394-424. https://doi. org/10.3322/caac.21492 PMID:30207593

3. Ferlay J, Colombet M, Soerjomataram I, Mathers C, Parkin DM, Piñeros M, Znaor A, Bray F (2019). Estimating the global cancer incidence and mortality in 2018: GLOBOCAN sources and methods. Int J Cancer. 144(8):1941-1953. https://doi.org/10.1002/ ijc.31937 PMID:30350310

4. Znaor A, van den Hurk $C$, Primic-Zakelj $M$, Agius D, Coza D, Demetriou A, Dimitrova N, Eser $\mathrm{S}$, Karakilinc H, Zivkovic S, Bray F, Coebergh JW. Cancer incidence and mortality patterns in South Eastern Europe in the last decade: Gaps persist compared with the rest of Europe Eur J Cancer. 2013 May;49(7):1683-91. doi: 10.1016/j. ejca.2012.11.030. Epub 2012 Dec 19.

5. Mihajlović J, Pechlivanoglou P, Miladinov-Mikov M, Zivković S, Postma MJ. Cancer incidence and mortality in Serbia 1999-2009. BMC Cancer. 2013;13:18. Published 2013 Jan 15. doi:10.1186/1471-2407-1318

6. Markovic-Denic L, Cirkovic A, Zivkovic S, Stanic D, Skodric-Trifunovic V. Cancer Mortality in Central Serbia. J BUON. 2014 Jan-Mar;19(1):273-7.

7. Markovic-Denic LjN, Zivkovic SV, Sipetic SB, Vlajinac HD, Kocev NI, Marinkovic JM. Time trends in cancer mortality in Central Serbia, Soz Praven- tivmed. 2006;51(2):117-22. doi: 10.1007/s00038005-0023-7

8. Japanese Gastric Cancer Association. Japanese gastric cancer treatment guidelines 2018 (5th edition). Gastric Cancer (2020). https://doi. org/10.1007/s10120-020-01042-y

9. Ahn HJ, Lee DS. Helicobacter pylori in gastric carcinogenesis, World J Gastrointest Oncol. 2015 Dec 15;7(12):455-65. doi: 10.4251/wjgo.v7.i12.455.

10. Polk DB, Peek RM Jr. Helicobacter pylori: gastric cancer and beyond. Nat Rev Cancer. 2010 Jun;10(6):403-14. doi: 10.1038/nrc2857.

11. Ford AC, Axon AT. Epidemiology of Helicobacter pylori infection and public health implications. Helicobacter. 2010 Sep;15 Suppl 1:1-6. doi: 10.1111/j.1523-5378.2010.00779.x.

12. James K.Y. Hooi, Wan Ying Lai, Wee Khoon Ng, Michael M.Y. Suen, Fox E. Underwood, Divine Tanyingoh, Peter Malfertheiner, Y. Graham, Vincent W.S. Wong, Justin C.Y. Wu, Francis K.L. Chan, Joseph J.Y. Sung, Gilaad G. Kaplan. Global Prevalence of Helicobacter pylori Infection: Systematic Review and Meta-Analysis, Siew C. Ng , Published:April 26, 2017, https://doi.org/10.1053/j.gastro.2017.04.022

13. Helicobacter and Cancer Collaborative Group [Corporate Author] Gastric cancer and Helicobacter pylori: a combined analysis of 12 case control studies nested within prospective cohorts. Gut 2001 Sep;49(3):347-53. doi: 10.1136/gut.49.3.347.

14. de Martel C, Ferlay J, Franceschi S, Vignat J, Bray F, Forman D, Plummer M.Global burden of cancers attributable to infections in 2008: a review and synthetic analysis.Lancet Oncol. 2012 Jun;13(6):60715. doi: 10.1016/S1470-2045(12)70137-7.

15. Hansson LE, Engstrand L, Nyrén O, Evans DJ $\mathrm{Jr}$, Lindgren A, Bergström R, Andersson B, Athlin L, Bendtsen O, Tracz P.Helicobacter pylori infection: independent risk indicator of gastric adenocarcinoma. Gastroenterology 1993:105;1098-103.doi: 10.1016/0016-5085(93)90954-b.

16. Parsonnet J, Friedman GD, Vandersteen DP, Chang Y, Vogelman JH, Orentreich N, Sibley RK. Helicobacter pylori infection and the risk of gastric carcinoma. N Engl J Med 1991:325; 1127-31.doi: 10.1056/NEJM199110173251603.

17. Uemura N, Okamoto S, Yamamoto S, et al. Helicobacter pylori infection and the development of gastric cancer. N Engl J Med 2001;345: 784-9.

18. Malfertheiner $P$, Bornschein J, Selgrad $M$. Role of Helicobacter pylori infection in gastric cancer pathogenesis: a chance for prevention. J Dig Dis 2010;11:2-11.doi: 10.1111/j.17512980.2009.00408.x.

19. Take S, Mizuno M, Ishiki K, Nagahara Y, Yoshida T, Yokota K, Oguma K, Okada H, Shiratori Y. The effect of eradicating Helicobacter pylori on the development of gastric cancer in patients with peptic ulcer 
disease. Am J Gastroenterol. 2005 May;100(5):103742. doi: 10.1111/j.1572-0241.2005.41384.x.

20. Parsonnet J, Friedman GD, Orentreich N, Vogelman $\mathrm{H}$. Risk for gastric cancer in people with CagA positive or CagA negative Helicobacter pylori infection. Gut 1997;40:297-301. doi: 10.1136/ gut.40.3.297.

21. Odenbreit S, Püls J, Sedlmaier B, Gerland E, Fischer W, Haas R. Translocation of Helicobacter pylori CagA into gastric epithelial cells by type IV secretion. Science. 2000 Feb 25;287(5457):1497500. doi: $10.1126 /$ science.287.5457.1497.

22. Kwok T, Zabler D, Urman S, Rohde M, Hartig R, Wessler S, Misselwitz R, Berger J, Sewald N, König W, Backert S. Helicobacter exploits integrin for type IV secretion and kinase activation. Nature. 2007 Oct 18;449(7164):862-6. doi: 10.1038/nature06187.

23. Hatakeyama M. Oncogenic mechanisms of the Helicobacter pylori CagA protein. Nat Rev Cancer. 2004 Sep;4(9):688-94. doi: 10.1038/nrc1433.

24. Atherton JC, Peek RM Jr, Tham KT, Cover TL, Blaser MJ. Clinical and pathological importance of heterogenecity in VacA, the vacuolating cytotoxin gene of Helicobacter pylori. Gastroenterology. 1997 Jan;112(1):92-9. doi: 10.1016/s00165085(97)70223-3.

25. Wolf EM, Geigl JB, Svrcek M, Vieth M, Langner $C$. Hereditary gastric cancer. Pathologe. 2010 Oct;31(6):423-9. doi: 10.1007/s00292-010-1353-7.

26. Freedman ND, Abnet CC, Leitzmann MF, Mouw T, Subar AF, Hollenbeck AR, Schatzkin A. A prospective study of tobacco, alcohol and the risk of esophageal and gastric cancer subtypes. Am J Epidemiol. 2007 Jun 15;165(12):1424-33. doi: 10.1093/aje/ kwm051. Epub 2007 Apr 9.

27. Woodward M, Tunstall-Pedoe H, McColl K. Helicobacter pylori infection reduces systemic availability of dietary vitamin C. Eur J Gastroen- terol Hepatol 2001;13:317-22.

28. You WC, Zhang L, Gail MH, Chang YS, Liu WD, Ma JL, Li JY, Jin ML, Hu YR, Yang CS, Blaser MJ, Correa P, Blot WJ, Fraumeni JF Jr, Xu GW. Gastric dysplasia and gastric cancer: Helicobacter pylori, serum vitamin C, and other risk factors. J Natl Cancer Inst. 2000 Oct 4;92(19):1607-12. doi: 10.1093/ jnci/92.19.1607.

29. Buckland G, Agudo A, Luján L, Jakszyn P, Buenode-Mesquita HB, Palli D, Boeing H, Carneiro F, Krogh V, Sacerdote C, Tumino R, Panico S, Nesi G, Manjer J, Regnér S, Johansson I, Stenling R, Sanchez MJ, Dorronsoro M, Barricarte A, Navarro C, Quirós JR, Allen NE, Key TJ, Bingham S, Kaaks R, Over$\operatorname{vad} K$, Jensen $M$, Olsen A, Tjønneland A, Peeters $\mathrm{PH}$, Numans ME, Ocké MC, Clavel-Chapelon F, Morois $S$, Boutron-Ruault $M C$, Trichopoulou A, Lagiou $P$, Trichopoulos D, Lund E, Couto E, Boffeta P, Jenab M, Riboli E, Romaguera D, Mouw T, González CA. Adherence to a Mediterranean diet and risk of gastric adenocarcinoma within the European Prospective
Investigation into Cancer and Nutrition (EPIC) cohort study. Am J Clin Nutr. 2010 Feb;91(2):381-90. doi: 10.3945/ajen.2009.28209. Epub 2009 Dec 9.

30. OhaOhata H, Kitauchi S, Yoshimura N, Mugitani $\mathrm{K}$, Iwane $\mathrm{M}$, Nakamura H, Yoshikawa A, Yanaoka K, Arii K, Tamai H, Shimizu Y, Takeshita T, Mohara $\mathrm{O}$, Ichinose $\mathrm{M}$. ta $\mathrm{H}$, Kitauchi $\mathrm{S}$, Yoshimura $\mathrm{N}$ i sur. Progression of chronic atrophic gastritis associated with Helicobacter pylori infection increases risk of gastric cancer. Int J Cancer. 2004 Mar;109(1):13843. doi: $10.1002 / \mathrm{ijc} .11680$.

31. Namikawa T, Hanazaki K. Mucin phenotype of gastric cancer and clinicopathology of gastrictype differentiated adenocarcinoma. World J Gastroenterol 2010;16:4634-9.

32. Malfertheiner $P$. The intriguing relationship of $\mathrm{H}$. pylori infection and acid secretion in peptic ulcer disease and gastric cancer. Dig Dis 2011; 29:459-64.

33. Wong BC, Lam SK, Wong WM, Chen JS, Zheng TT, Feng RE, Lai KC, Hu WH, Yuen ST, Leung SY, Fong DY, Ho J, Ching CK, Chen JS; China Gastric Cancer Study Group. Helicobacter pylori eradication to prevent gastric cancer in a high-risk region of China: a randomized controlled trial. JAMA. 2004 Jan 14;291(2):187-94. doi: 10.1001/jama.291.2.187.

34. Selgrad M, Bornschein J, Malfertheiner P. Guidelines for treatment of Helicobacter pylori in the East and West. Expert Rev Anti Infect Ther 2011;9:581-8.

35. Fuccio L, Zagari RM, Eusebi LH, Laterza L, Cennamo V, Ceroni L, Grilli D, Bazzoli F. Meta-analysis: can Helicobacter pylori eradication treatment reduce the risk for gastric cancer? Ann Intern Med. 2009 Jul 21;151(2):121-8. doi: 10.7326/0003-4819151-2-200907210-00009.

36. Malfertheiner P, Megraud F, O'Morain C, Bazzoli F, El-Omar E, Graham D, Hunt R, Rokkas T, Vakil N, Kuipers EJ. Current concepts in the management of Helicobacter pylori infection: the Maastricht III Con- sensus Report. Gut 2007;56:772-81.doi: 10.1136/gut.2006.101634. Epub 2006 Dec 14.

37. Malfertheiner $\mathrm{P}$, Megraud F, O'Morain CA, Atherton J, Axon AT, Bazzoli F, Gensini GF, Gisbert JP, Graham DY, Rokkas T, El-Omar EM, Kuipers EJ; European Helicobacter Study Group. Management of Helicobacter pylori infection the Maastricht IV/ Florence Consensus Report. Gut 2012;61:646-64. doi: 10.1136/gutjnl-2012-302084

38. Ley C, Mohar A, Guarner J et al. Helicobacter pylori eradication and gastric preneoplastic conditions: a randomized, double-blind, placebo controlled trial. Cancer Epidemiol Biomarkers Prev 2004;13:4-10.

39. Ford AC, Forman D, Bailey AG, Axon AT, Moayyedi P. A community screening program for Helicobacter pylori saves money:10-year follow up of a randomized controlled trial. Gastroenterology. 2005 Dec;129(6):1910-7. doi: 10.1053/j.gastro.2005.09.016. 
40. Ford AC, Forman D, Bailey AG, Axon AT, Moayyedi P. Does Helicobacter pylori eradication therapy for peptic ulcer prevent gastric cancer? World J Gastroenterol 2009;15:4290-7.

41. Fukase K, Kato M, Kikuchi S, Inoue K, Uemura N, Okamoto S, Terao S, Amagai K, Hayashi S, Asaka M; Japan Gast Study Group. Effect of eradication of Helicobacter pylori on incidence of metachronous gastric carcinoma after endoscopic resection of early gastric cancer: an open-label, randomised controlled trial. Lancet 2008;372:392-7.doi: 10.1016/S0140-6736(08)61159-9.

42. Dinis-Ribeiro M, Areia M, de Vries AC, MarcosPinto R, Monteiro-Soares $M$, O'Connor A, Pereira C, Pimentel-Nunes P, Correia R, Ensari A, Dumonceau JM, Machado JC, Macedo G, Malfertheiner P, Matysiak-Budnik T, Megraud F, Miki K, O'Morain C, Peek RM, Ponchon T, Ristimaki A, Rembacken B, Carneiro F, Kuipers EJ; European Society of Gastrointestinal Endoscopy; European Helicobacter Study Group; European Society of Pathology; Sociedade Portuguesa de Endoscopia Digestiva. Management of precancerous conditions and lesions in the stomach (MAPS): guideline from the European Society of Gastrointestinal Endoscopy, European Helicobacter Study Group, European Society of Pathology, and the Sociedade Portuguesa de Endoscopia Digestiva. Endoscopy. 2012 Jan;44(1):74-94. doi: 10.1055/s0031-1291491.

43. Marković SZ, Kastratović DA, Kubiak C, Demotes Mainard J. ECRIN - Needed in European Science. Hospital Pharmacology - International ultidisciplinary Journal 2015; 2(2):279-282.doi:10.5937/ hpimj1502279M (www.hophonline.org)

44. Marković SZ, Vuković MH, Kocev NI, Kastratović DA, Vukmirović SN. Statistical Methodes Applied in Pharmacotherapy. Hospital Pharmacology - International Multidisciplinary Journal . 2019; 6(1):747755. doi:10.5937/hpimj1901747M (www.hophonline.org) 


\title{
Helicobacter pylori i karcinom želuca
}

\author{
Snežana V. Živković-Perišić
}

Institut za javno zdravlje Srbije „dr Milan Jovanović Batut”, Beograd, Srbija

\section{KRATAK SADRŽAJ}

Uvod: Prema procenama GLOBOCAN-a za 2018. godinu, karcinom želuca je bio peti najčešći rak u obolevanju i treći najčešći uzrok smrtnosti izazvane malignim bolestima u svetu. lako je etiologija ovog karcinoma višestruka, infekcija Helicobacter pylori je snažno povezana sa nastankom karcinoma želuca.

Metodologija: Pregled strućnih međunarodnih časopisa i javnozdravstvenih publikacija vezanih za povezanost Helicobacter pylori infekcije i raka želuca.

Tema: Međunarodna Agencija za istraživanje raka i Svetska zdravstvena organizacija su još 1994. godine, odredile Helicobacter pylori kao kancerogen tip I kod ljudi, iako tačan mehanizam karcinogeneze još uvek nije jasno utvrđen. Na karcinogenezu utiču i faktori okoline, kao i genetska raznolikost, što može dovesti do različitih inflamatornih odgovora i tako uticati na klinički ishod bolesti. Hronični gastritis izazvan infekcijom Helicobacter pylori je najjači poznati faktor rizika za razvoj adenokarcinoma distalnog dela želuca. Efekat eradikacije Helicobacter pylori infekcije vidi se u smanjenom riziku od raka želuca, ali više terapijskih pokušaja da se iskorenjivanjem infekcije Helicobacter pylori spreči nastanak tumora želuca je dalo minimalne rezultate. U pokušaju da razjasne ovaj problem kod visoko rizičnih populacija, istraživači su počeli da sprovode prospektivne randomizirane, dvostruko slepe studije populacije. Rezultati prethodnih studija istakli su važnost dugoročnog i pažljivog praćenja pacijenatanakon sprovedene eradikacione terapije, ali i dalje postoje višestruka odstupanja („enigme”) koja dovode u pitanje uzročno-posledičnu vezu između $H$. pylori i karcinoma želuca.

Zaključak: Utvrđeno je, da je eradikacija Helicobacter pylori, u cilju prevencije karcinoma želuca efikasna samo kada se sprovodi pre razvoja premalignih promena: atrofije, metaplazije i displazije sluznice želuca. Pored toga, značajna efikasnost lečenja koja se primećuje kod mlađih pacijenata sugeriše potrebu da se iskorenjivanje infekcije Helicobacter pylori izvrši što je ranije moguće.

Ključne reči: Helicobacter pylori infekcija, karcinogeneza, rak želuca 